\title{
PERANAN TEKNIK SPLIT-BOLUS TERHADAP KUALITAS CITRA PADA PEMERIKSAAN MSCT LEHER
}

\author{
$\underline{{ }^{1} \text { Hefty Lustyana Devi, }{ }^{2} \text { Bekti Safarini, }{ }^{3} \text { Nanang Sulaksono }}$ \\ ${ }^{1,3}$ Poltekkes Kemenkes Semarang \\ ${ }^{2}$ RSI Sultan Agung Semarang \\ Corresponding author: Hefty Lustyana Devi \\ Email : heftylustyana@gmail.com
}

\begin{abstract}
Background : According to the theory, Neck MSCT examination were performed using monophasic injection techniques. Split-bolus is an innovative technique that divides intravenous (IV) contrast media into two or three boluses and combines phase images in single scanning. The MSCT split-bolus scan with a combination of parenchymal and vascular enhancement is a valid alternative approach compared to the standard monophasic MSCT protocol. The purpose of this study was to determine the split-bolus technique in neck MSCT examination and its role in the quality of the image.

Method : This research is a descriptive qualitative study with a literature review study method. Data is collected by the documentation method. The electronic database was searched using the keywords "head and neck" AND ("contrast" OR "injection") AND ("Split bolus" OR "Biphasic Contrast" OR "Dual bolus" OR "Double bolus" OR "Multi-phase" OR "Quadruple-Phase"). The inclusion criteria used were a research article on a split-bolus technique in a single scan on MSCT neck examination. Three articles met the inclusion criteria. Data analysis was performed using the annotated bibliography method.

Result : The results of this study indicate that the contrast media used in the MSCT examination of the neck with a split-bolus technique are non-ionic iodine contrast media with a total volume of $80-100 \mathrm{~mL}$ and a concentration of $300-370 \mathrm{mg} / \mathrm{mL}$. Contrast media injection is done by dividing contrast media in the first and second boluses using a ratio of $3: 2$ or $1: 1$ of the total volume of contrast media followed by saline injection. The flow rate used is $2-3 \mathrm{~mL} / \mathrm{s}$ with a fixed delay time between $70-120$ seconds. The split - bolus techniques have a role in contrast resolution of image quality. The image quality produced on neck MSCT examination using split bolus technique can increase vaskular and tumor enhancement without reducing parenchymal enhancement and lesions. In a patient with metastasis, this technique can reduce artifacts due to excessive contrast media in the arteries and veins so the lymph nodes appear more clearly.

Conclusion : Based on the result, the split - bolus techniques have a role in contrast resolution of image quality.
\end{abstract}

Keywords: Neck MSCT, Split-Bolus Techniques, Contrast Media Injection

\section{Latar Belakang}

Leher merupakan area antara basis cranii dan batas inferior mandibular dan aperture thoracic superior (Docherty, 2012). Dalam anatomi terdapat istilah soft tissue dan hard tissue. Soft tissue meliputi tendon, ligament, fasia, kulit, jaringan fibrosa, lemak, membrane synovial, otot, saraf, dan pembuluh darah, sedangkan tulang merupakan hard tissue (National Cancer Institute, 2019). Ada banyak struktur penting yang terletak di area leher antara lain tulang, otot, spinal cord, pembuluh darah, saraf, serta kelenjar tiroid dan paratiroid. Vertebrae cervical merupakan struktur tulang utama pada leher. Tulang-tulang dan otot-otot pada leher berfungsi sebagai penyokong kepala dan berperan pada gerakan kepala (Applegate, 2010).

Teknologi CT telah berkembang pesat selama 8 tahun terakhir dengan diperkenalkannya multislice CT (MSCT) ke praktik radiologi klinis MSCT menjadi pilihan untuk studi berbagai organ pada klinis yang beragam karena memungkinkan kolimasi irisan-irisan yang lebih tipis dengan visualisasi detail anatomi yang lebih baik. Selain itu, MSCT juga bisa digunakan untuk menghitung rekonstruksi multiplanar (MPR) dari set volume data yang discan serta waktu scanning menjadi lebih cepat (Laghi, 2012).
Teknologi CT baru telah memperkenalkan tantangan baru, terutama dalam menstandarisasi protokol, mengelola dosis radiasi, mengelola set data gambar, dan memastikan efisiensi diagnostik (Kyongtae T. Bae, 2010). Pada pemeriksaan MSCT, lesi dapat diidentifikasi baik di dalam maupun di sekitar organ dengan menggunakan media kontras intravena, organ padat dan sifatnya terlihat dari pola enhancement-nya. Berbagai bentuk media kontras telah digunakan untuk meningkatkan pencitraan medis. Peranannya telah lama diakui, dibuktikan dengan penggunaan media kontras sehari-hari yang umum di departemen radiologi di seluruh dunia. Namun, seperti obat-obatan lainnya, agen kontras ini tidak sepenuhnya bebas resiko. Metode injeksi bervariasi tergantung pada akses vaskuler, diagnosis banding, dan tipe pemeriksaan radiologinya. Mode dan metode injeksi, baik dengan tangan (manual) ataupun dengan injektor juga bervariasi berdasarkan prosedur (ACR Manual on Contrast Media Version 10.3, 2018).

Pemeriksaan MSCT leher dilakukan dengan menggunakan teknik injeksi monofasik standar. Jenis media kontras yang digunakan yaitu media kontras iodine non ionik dengan konsentrasi $300 \mathrm{mg} / \mathrm{mL}$ dan volume total $60-90 \mathrm{~mL}$. Injeksi media kontras dilakukan menggunakan flow rate 2 
$\mathrm{mL} / \mathrm{s}$ dan scan delay time 60 detik (Wijokongko dkk., 2016; Mittal dan Dhawan, 2019).

Split-bolus merupakan teknik inovatif yang membagi media kontras intravena (IV) menjadi dua atau tiga bolus dan menggabungkan gambar fase dalam single scanning, dapat digunakan pada pasien kanker untuk mengurangi dosis radiasi (Scialpi $d k k$., 2014). Single scan split-bolus MSCT dengan kombinasi enhancement parenkim dan vaskuler merupakan pendekatan alternatif yang valid dibandingkan dengan protokol MSCT monofasik standar (Scialpi dkk., 2015). Gagasan ini pertama kali dimulai di bidang pencitraan aorta. Penggunaan teknik ini paling banyak dipelajari dalam pemeriksaan genitourinary untuk menyingkronisasi akuisisi enhancement parenkim ginjal dan opasifikasi saluran urin Teknik ini juga telah diterapkan untuk evaluasi lesi pankreas dan hati (Kim $d k k ., 2017)$.

Literatur yang terkait dengan penggunaan teknik splitbolus pada pemeriksaan MSCT leher diantaranya dua jurnal penelitian (J. H. Lee $d k k$., 2012; Saade $d k k$., 2016) dan satu prosiding dari The European Congress of Radiology (ECR) yang diadakan di Vienna, Austria (Weiner $d k k ., 2010)$. Dalam jurnalnya, Saade $d k k$., (2016) membandingkan kualitas citra, dosis radiasi, dan artefak yang dihasilkan dari penggunaan teknik split-bolus dan tanpa teknik split-bolus pada pemeriksaan MSCT kepala dan leher pada evaluasi metastasis kanker kepala dan leher. Lee $d k k$., (2012) dalam jurnalnya membandingkan teknik split-bolus dan tanpa teknik splitbolus untuk mengevaluasi teknik injeksi dan scan delay time yang optimal dalam pemeriksaan MSCT kepala dan leher tanpa terfokus pada satu klinis. Sedangkan Weiner $d k k$., (2010) membandingkan teknik bifasik (teknik split-bolus) dan teknik monofasik (tanpa teknik split-bolus) pada pasien tumor kepala dan leher untuk mengevaluasi enhancement kontras pada tumor, pembuluh darah, dan jaringan lunak pada pemeriksaan MSCT kepala dan leher.

Kualitas citra dalam radiologi harus dapat memperlihatkan gambaran anatomi yang sesuai dan dapat memberikan nilai akurasi diagnostik yang tinggi. Ada empat faktor yang mempengaruhi kualitas citra CT Scan (Mahesh, 2013) yaitu spasial resolusi, kontras resolusi, artefak dan noise.

Jeavons dkk., (2018) menyatakan bahwa sebelum mengusulkan teknik baru untuk diterapkan dalam pemeriksaan, penting untuk memahami bagaimana teknik baru yang akan diterapkan. Berdasarkan latar belakang tersebut, penulis tertarik untuk melakukan kajian literature tentang penggunaan teknik split-bolus pada pemeriksaan MSCT leher, untuk itu penulis mengambil judul Skripsi "Peranan Teknik Split-Bolus Terhadap Kualitas Citra pada Pemeriksaan MSCT Leher".

\section{Metode}

Jenis penelitian ini adalah penelitan kualitatif deskriptif dengan metode penelitian kepustakaan (library research) atau kajian literature. Penelitian dilakukan dari bulan April - Juni 2020. Tempat pengumpulan data untuk penelitian kepustakaan tidak mengenal batas ruang. Data dapat diperoleh dari perpustakaan maupun internet yang dapat diakses dimanapun. Metode pengambilan data yang digunakan dalam penelitian ini adalah metode dokumentasi. Data yang digunakan dalam penelitian ini adalah data sekunder yang diperoleh dari hasil penelitian yang telah dilakukan oleh peneliti-peneliti terdahulu. Sumber data sekunder yang dimaksud berupa buku dan laporan ilmiah primer atau asli yang terdapat di dalam artikel atau jurnal (tercetak dan/atau non-cetak) berkenaan dengan teknik split-bolus pada pemeriksaan CT leher dan peranannya terhadap kualitas citra yang dihasilkan.

Pencarian literatur dilakukan pada database online yang memiliki repository besar untuk studi akademis seperti Google Scholar, PMC, ScienceDirect, Pubmed, dan Cochrane Library dengan keyword berikut "head and neck" AND ("contrast" OR "injection") AND ("Split bolus" OR "Biphasic Contrast" OR "Dual bolus" OR "Double bolus" OR "Multi-phase" OR "Quadruple-Phase"). Beberapa filter pencarian digunakan dalam setiap database, yakni : Google Scholar menggunakan filter "allintitle", ScienceDirect menggunakan filter "research articles", PMC menggunakan filter "MEDLINE journals", Semua menggunakan filter waktu "10 tahun terakhir".

Sumber data utama penelitian ini adalah 3 jurnal yang dipilih oleh penulis berdasarkan seleksi yang telah dilakukan. Berikut sumber utama yang digunakan dalam penelitian :

a. Comparison Of Standard And Quadruple-Phase Contrast Material Injection For Artifacts, Image Quality, And Radiation Dose In The Evaluation Of Head And Neck Cancer Metastases (Saade dkk., 2016)

b. Usefulness Of Biphasic Contrast Injection In Multidetector CT Of The Head And Neck: A Comparison With Monophasic Contrast Injection (Lee $d k k ., 2012$ )

c. Monophasic Versus Biphasic Contrast Application In CT Of Patients With Head And Neck Tumour (Weiner $d k k$, 2010)

Analisis data yang digunakan dalam penelitian ini adalah analisis anotasi bibliografi (annotated bibliography). Anotasi berarti suatu kesimpulan sederhana dari suat artikel, buku, jurnal, atau beberapa sumber tulisan yang lain, sedangkan bibliografi diartikan sebagai suatu daftar sumber dari suatu topik. Dari kedua definisi tersebut, anotasi bibliografi diartikan sebagai suatu daftar sumber-sumber yang digunakan dalam suatu penelitian, dimana pada setiap sumbernya diberikan simpulan terkait dengan apa yang tertulis di dalamnya.

\section{Hasil}

Penelitian dilakukan terhadap 3 (tiga) jurnal yang relevan dengan pemeriksaaan MSCT leher dengan teknik split-bolus. Dari ketiga jurnal tersebut, dilakukan analisa mengenai teknik split bolus pada pemeriksaan MSCT leher dan peranannya terhadap kualitas citra yang dihasilkan. Perbandingan teknik injeksi kontras monofasik (tanpa splitbolus) dan teknik Bifasik (split-bolus) pada pemeriksaan MSCT Leher yang digunakan pada masing-masing jurnal ditunjukan pada tabel 1 . 
Tabel 1. Perbandingan teknik injeksi monofasik dan teknik split-bolus (Bifasik) pada pemeriksaan MSCT leher antar literature

\begin{tabular}{|c|c|c|c|c|c|c|}
\hline \multirow{2}{*}{ Kategori } & \multicolumn{2}{|c|}{ Jurnal 1 (Saade., dkk) } & \multicolumn{2}{|c|}{ Jurnal 2 (Lee., dkk) } & \multicolumn{2}{|c|}{ Jurnal 3 (Weiner., dkk) } \\
\hline & Monofasik & Bifasik & Monofasik (M) & Bifasik (B) & Monofasik & Bifasik \\
\hline Jenis Media Kontras & Optiray & Optiray & Omnipaque & Omnipaque & Iopromide & Iopromide \\
\hline $\begin{array}{c}\text { Konsentrasi Media } \\
\text { Kontras }\end{array}$ & $370 \mathrm{mg} / \mathrm{mL}$ & $\begin{array}{l}370 \\
\mathrm{mg} / \mathrm{mL}\end{array}$ & $300 \mathrm{mg} / \mathrm{mL}$ & $300 \mathrm{mg} / \mathrm{mL}$ & $300 \mathrm{mg} / \mathrm{mL}$ & $300 \mathrm{mg} / \mathrm{mL}$ \\
\hline Volume Media kontras & $100 \mathrm{~mL}$ & $100 \mathrm{~mL}$ & $\begin{array}{l}\mathrm{M}_{1,2}=100 \mathrm{~mL} \\
\mathrm{M}_{3}=100 \mathrm{~mL}\end{array}$ & $\begin{array}{l}\mathrm{B}_{1,2}=100 \mathrm{~mL} \\
\mathrm{~B}_{3}=80 \mathrm{~mL}\end{array}$ & $100 \mathrm{~mL}$ & $100 \mathrm{~mL}$ \\
\hline $\begin{array}{c}\text { Pembagian Media } \\
\text { Kontras }\end{array}$ & Tidak ada & $3: 2$ & Tidak ada & $1: 1$ & Tidak ada & $3: 2$ \\
\hline Saline flush & $\mathrm{Ya}$ & $\mathrm{Ya}$ & $\mathrm{Ya}$ & $\mathrm{Ya}$ & $\mathrm{Ya}$ & $\mathrm{Ya}$ \\
\hline Volume Saline & $100 \mathrm{~mL}$ & $100 \mathrm{~mL}$ & $*$ & $*$ & $40 \mathrm{~mL}$ & $40 \mathrm{~mL}$ \\
\hline Delay inter bolus & Tidak ada & $*$ & Tidak ada & $*$ & Tidak ada & 60 detik \\
\hline Flow rate & $2.5 \mathrm{~mL} / \mathrm{s}$ & $2.5 \mathrm{~mL} / \mathrm{s}$ & $\begin{array}{l}\mathrm{M}_{1}=3 \mathrm{~mL} / \mathrm{s} \\
\mathrm{M}_{2,3}=2 \mathrm{~mL} / \mathrm{s}\end{array}$ & $\begin{array}{l}\mathrm{B}_{1}=3 \mathrm{~mL} / \mathrm{s} \\
\mathrm{B}_{2,3}=2 \mathrm{~mL} / \mathrm{s}\end{array}$ & $3 \mathrm{~mL} / \mathrm{s}$ & $\begin{array}{l}\text { Bolus } 1=2.5 \\
\mathrm{~mL} / \mathrm{s} \\
\text { Bolus } 2=3 \\
\mathrm{~mL} / \mathrm{s}\end{array}$ \\
\hline Scan delay time & 70 detik & 70 detik & $\begin{array}{l}\mathrm{M}_{1}=70 \text { detik } \\
\mathrm{M}_{2}=70 \text { detik } \\
\mathrm{M}_{3}=90 \text { detik }\end{array}$ & $\begin{array}{l}B_{1}=70 \text { detik } \\
B_{2}=120 \text { detik } \\
B_{3}=90 \text { detik }\end{array}$ & 50 detik & 120 detik \\
\hline \multicolumn{7}{|c|}{ Hasil Penempatan ROI (Mean \pm Standar Deviasi) } \\
\hline Penempatan ROI & Monofasik & Bifasik & Monofasik (M) & Bifasik (B) & Monofasik & Bifasik \\
\hline Arteri & $160 \pm 29$ & $234 \pm 33$ & $\begin{array}{l}M_{1}=190 \pm 21 \\
M_{2}=204 \pm 23 \\
M_{3}=177 \pm 20\end{array}$ & $\begin{array}{l}\mathrm{B}_{1}=224 \pm 35 \\
\mathrm{~B}_{2}=189 \pm 20 \\
\mathrm{~B}_{3}=179 \pm 23\end{array}$ & $203 \pm 46$ & $311 \pm 65$ \\
\hline Vena & $664 \pm 12$ & $164 \pm 17$ & $\begin{array}{l}\mathrm{M}_{1}=198 \pm 19 \\
\mathrm{M}_{2}=215 \pm 27 \\
\mathrm{M}_{3}=183 \pm 21\end{array}$ & $\begin{array}{l}\mathrm{B}_{1}=243 \pm 31 \\
\mathrm{~B}_{2}=198 \pm 19 \\
\mathrm{~B}_{3}=209 \pm 34\end{array}$ & $199 \pm 40$ & $267 \pm 87$ \\
\hline Otot Sternokleidomastoid & $*$ & * & $\begin{array}{l}\mathrm{M}_{1}=79 \pm 9 \\
\mathrm{M}_{2}=78 \pm 8 \\
\mathrm{M}_{3}=80 \pm 4\end{array}$ & $\begin{array}{l}\mathrm{B}_{1}=77 \pm 6 \\
\mathrm{~B}_{2}=78 \pm 9 \\
\mathrm{~B}_{3}=78 \pm 10\end{array}$ & $64 \pm 7$ & $69 \pm 8$ \\
\hline Kelenjar getah bening & $*$ & $*$ & $\begin{array}{l}M_{1}=113 \pm 12 \\
M_{2}=112 \pm 17 \\
M_{3}=109 \pm 11\end{array}$ & $\begin{array}{l}\mathrm{B}_{1}=117 \pm 19 \\
\mathrm{~B}_{2}=111 \pm 14 \\
\mathrm{~B}_{3}=103 \pm 10\end{array}$ & $*$ & $*$ \\
\hline Kelenjar Submandibular & $*$ & * & $\begin{array}{l}M_{1}=121 \pm 26 \\
M_{2}=127 \pm 20 \\
M_{3}=107 \pm 28\end{array}$ & $\begin{array}{l}\mathrm{B}_{1}=118 \pm 21 \\
\mathrm{~B}_{2}=121 \pm 25 \\
\mathrm{~B}_{3}=107 \pm 16\end{array}$ & $79 \pm 20$ & $98 \pm 35$ \\
\hline Tumor & $*$ & $*$ & $*$ & $*$ & $82 \pm 17$ & $118 \pm 30$ \\
\hline \multicolumn{7}{|c|}{ Penilaian Kualitas Citra } \\
\hline AVCR & $<0,85$ & $>1,30$ & * & $*$ & * & $*$ \\
\hline CNR & $14,5 \pm 14$ & $34,4 \pm 9$ & $*$ & $*$ & $*$ & $*$ \\
\hline Artefak & Ada & Tidak ada & $*$ & $*$ & $*$ & $*$ \\
\hline
\end{tabular}

Keterangan :

*Tidak dijelaskan

$\mathrm{M}_{1,2,3}$ : Monofasik 1, 2, 3 dan $\mathrm{B}_{1,2,3}$ : Bifasik 1, 2, 3. $\mathrm{M}_{1}$ vs $\mathrm{B}_{1}$ untuk mengetahui pengaruh teknik injeksi monofasik dan bifasik terhadap citra yang dihasilkan, $M_{2}$ vs $B_{2}$ untuk mengetahui pengaruh perbedaan time scan delay, sedangkan $M_{3}$ dan $B_{3}$ untuk menilai apakah teknik split bolus mampu mengurangi total volume media kontras yang digunakan.

Dari tabel di atas didapatkan beberapa data hasil yakni :

a. Media kontras yang digunakan pada pemeriksaan MSCT leher dengan teknik split bolus sama dengan media kontras yang digunakan menggunakan teknik monofasik yakni Optiray (Jurnal 1), omnipaque (Jurnal 2), dan iopromide (Jurnal 3) dengan konsentrasi $300 \mathrm{mg} / \mathrm{mL}$ (Jurnal 2, 3) dan $370 \mathrm{mg} / \mathrm{mL}$ (Jurnal 1). Volume media kontras yang digunakan $80-100 \mathrm{~mL}$ pada Jurnal 2 dan $100 \mathrm{~mL}$ pada jurnal 1 dan 3 . Ada pembagian media kontras pada teknik bifasik (3 : 2 pada jurnal 1,3 dan 1 : 1 pada jurnal 2), sedangkan pada teknik monofasik tidak ada. Ketiga jurnal menggunakan salin flush dengan volume $40 \mathrm{~mL}$ (Jurnal 3) dan $100 \mathrm{~mL}$ (Jurnal 1). Dari tiga jurnal, hanya jurnal 3 yang menggunakan delay interbolus dengan waktu delay 
60 detik. Flow rate yang digunakan $2 \mathrm{~mL} / \mathrm{s}$ (Jurnal 2), 2,5 $\mathrm{mL} / \mathrm{s}$ (Jurnal 1,3) dan $3 \mathrm{~mL} / \mathrm{s}$ (Jurnal 2,3). Scan delay time yang digunakan pada teknik monofasik adalah 50 detik (Jurnal 3), 70 detik (Jurnal 1,2) dan 90 detik (Jurnal 2), sedangkan pada teknik bifasik pada jurnal 1 menggunakan scan delay time 70 detik, Jurnal 2 menggunakan 70-120 detik, dan Jurnal 3 menggunakan 120 detik.

b. Hasilnya, dilihat dari penempatan ROI, pada Jurnal 1 ada kenaikan enhancement arteri dan penurunan enhancement vena pada teknik split bolus. Pada jurnal 2 dan 3 ada kenaikan enhancement vaskuler baik vena maupun arteri pada teknik split bolus, tanpa ada perbedaan signifikan enhancement jaringan lunak antara teknik monofasik dan bifasik (split bolus). Pada Jurnal 3 tampak ada kenaikan enhancement tumor pada teknik split bolus. Dilihat dari penilaian kualitas citranya di Jurnal 1, nilai AVCR dan CNR pada teknik split bolus lebih tinggi dari teknik monofasik, dan tampak artefak pada teknik monofasik tetapi pada teknik split bolus tidak ada artefak.

Hasil citra pemeriksaan MSCT leher dengan teknik monofasik dan Split-bolus (bifasik) menurut jurnal 1 ditunjukan pada gambar 1 dan 2 , menurut jurnal 2 ditunjukan pada gambar 3, dan menurut jurnal 3 ditunjukan pada gambar 4.

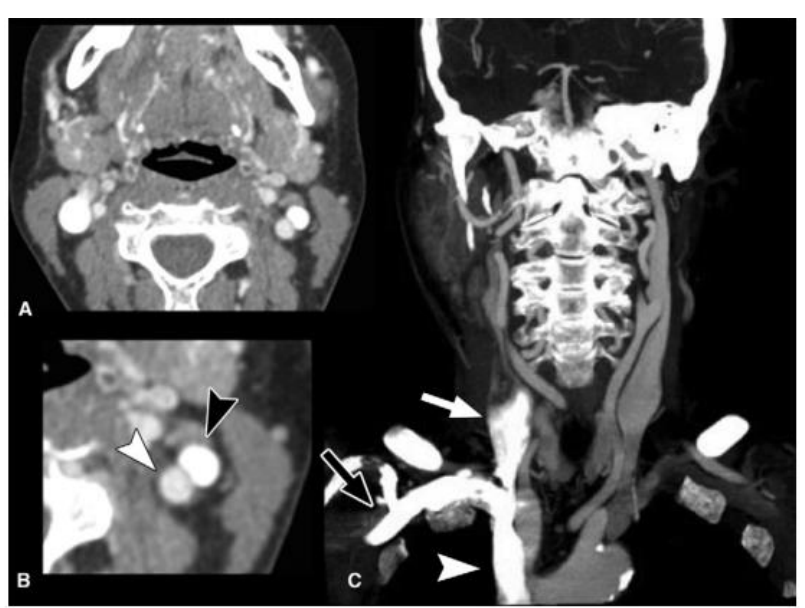

Gambar 1. Citra MSCT leher pada seorang wanita 47 tahun, diperoleh dengan metode dual-phase (tanpa split-bolus), menunjukkan artefak perivenous yang mengganggu interpretasi gambar. A, B, Gambar aksial mengurangi AVCR antara arteri karotis internal (panah hitam pada B) dan vena jugularis internal (panah putih pada B). C, gambar coronal menunjukkan refluks bahan kontras ke dalam vena jugularis internal (panah putih), BCV (Brachiocephalic vein) (panah hitam), dan vena cava superior (panah), mengaburkan evaluasi arteri vertebralis.
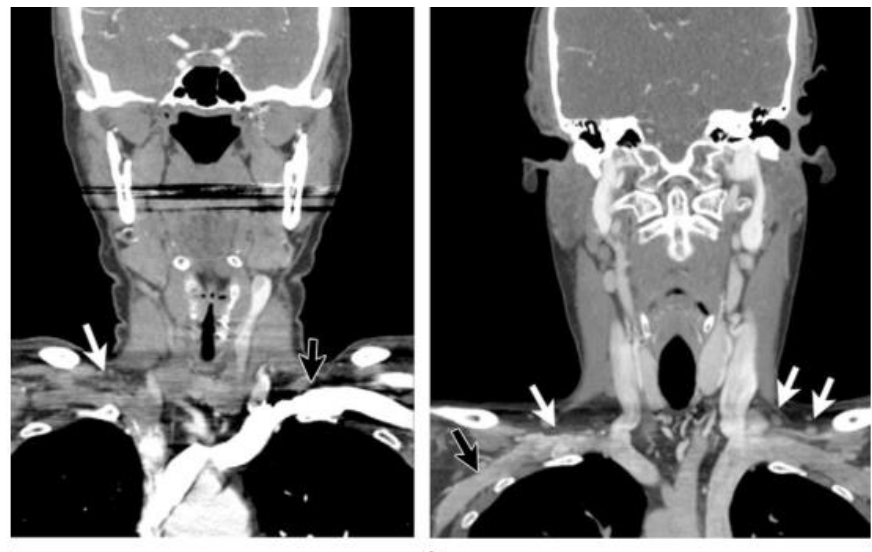

b.

Gambar 2. Citra MSCT leher dengan dan tanpa split-bolus.

(a) Gambar CT leher potongan coronal dari seorang wanita 63 tahun. Bahan kontras redundan yang masuk (panah hitam) discan 70 detik setelah injeksi, dengan visualisasi yang buruk dari kelenjar getah bening (panah putih) pada cervicothoracic junction. (b) Gambar CT leher potongan koronal dari seorang pria berusia 58 tahun. Teknik injeksi kontras split-bolus digunakan, di mana visualisasi lengkap dari kelenjar getah bening (panah putih) ditampilkan karena ada washout total bahan kontras yang berlebihan di BCV (panah hitam).
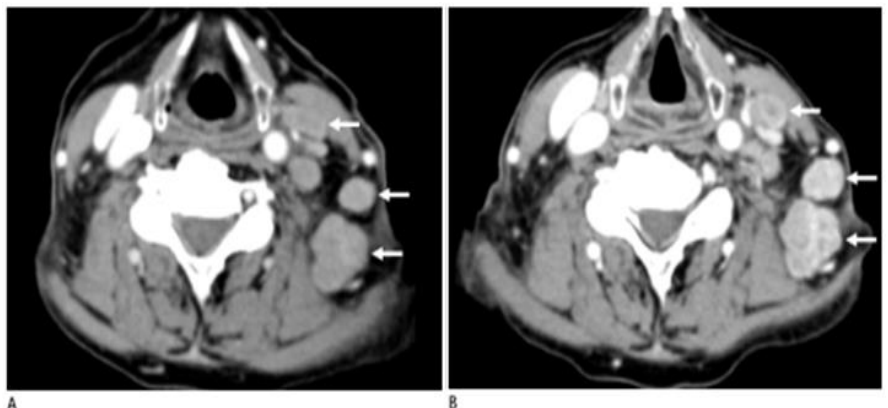

Gambar 3. CT kepala dan leher serial dilakukan dengan protokol injeksi kontras yang berbeda pada pria 75 tahun dengan multiple metastasis kelenjar getah bening di rantai jugularis kiri. CT awal (A) dicapai dengan protokol injeksi kontras monofasik (media kontras, $100 \mathrm{~mL}$; laju injeksi, $2 \mathrm{~mL}$ / detik; dan scan delay time, 70 detik). Dua minggu kemudian, CT kedua (B) dilakukan dengan protokol injeksi kontras bifasik (media kontras, $100 \mathrm{~mL}$; laju injeksi, $2 \mathrm{~mL} /$ detik; injeksi bolus kontras awal kedua $50 \mathrm{~mL}$ dan injeksi bolus kontras tambahan $50 \mathrm{~mL}$ pada 35 detik setelah injeksi awal; time scan delay, 120 detik). Enhancement metastasis kelenjar getah bening (panah) lebih baik pada CT terakhir dengan delay time lebih lama dari CT awal; Namun, enhancement vaskular tidak menurun pada CT terakhir. Meskipun scan delay time panjang, injeksi kontras bifasik dapat memastikan enhancement pembuluh darah yang optimal. 


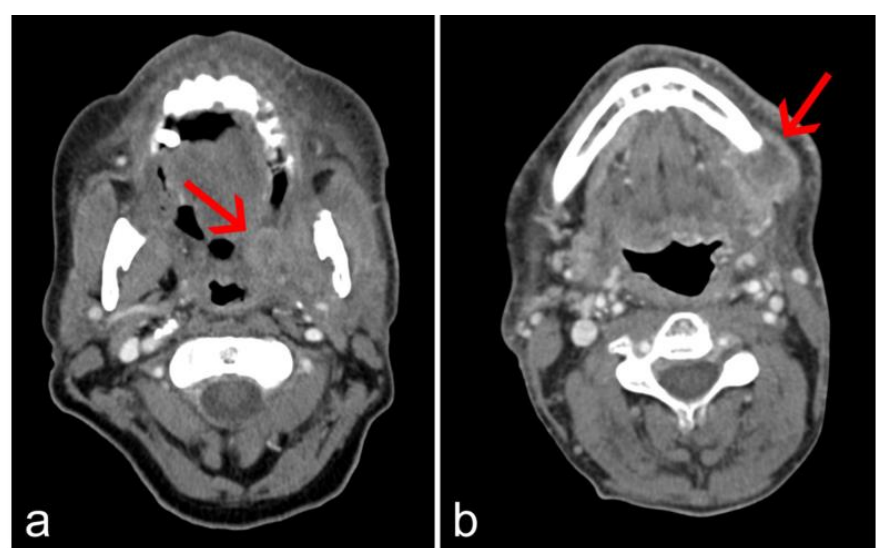

Gambar 4. Enhancement dan delineation tumor (panah merah) dengan protokol kontras monofasik (tanpa Split-bolus) (a) dan biphasic (Split-bolus) (b).

Berdasarkan citra yang dihasilkan pada pemeriksaan MSCT leher didapatkan perbandingan peranan teknik splitbolus pada pemeriksaan MSCT Leher yang digunakan pada masing-masing jurnal ditunjukan pada tabel 2 .

Tabel 2. Perbandingan peranan teknik split-bolus (Bifasik) terhadap kualitas citra pada MSCT leher antar literatur.

\begin{tabular}{|c|c|c|}
\hline Sumber & Monofasik & Bifasik \\
\hline $\begin{array}{l}\text { Jurnal } 1 \\
\text { (Saade., } \\
\text { dkk) }\end{array}$ & $\begin{array}{l}\text { Tampak adanya } \\
\text { artefak dan media } \\
\text { kontras yang berlebih } \\
\text { dengan visualisasi } \\
\text { kelenjar getah bening } \\
\text { yang buruk pada } \\
\text { cervicothoracic } \\
\text { junction }\end{array}$ & $\begin{array}{l}\text { Tampak visualisasi } \\
\text { lengkap dari kelenjar } \\
\text { getah bening karena } \\
\text { ada washout total } \\
\text { bahan kontras yang } \\
\text { berlebihan di BCV }\end{array}$ \\
\hline
\end{tabular}

\begin{tabular}{|c|c|c|}
\hline $\begin{array}{l}\text { Jurnal } 2 \\
\text { (Lee., } \\
\text { dkk) }\end{array}$ & $\begin{array}{l}\text { Enhancement } \\
\text { metastasis kelenjar } \\
\text { getah bening kurang } \\
\text { jelas }\end{array}$ & $\begin{array}{l}\text { Enhancement } \\
\text { metastasis kelenjar } \\
\text { getah bening tampak } \\
\text { lebih baik }\end{array}$ \\
\hline $\begin{array}{l}\text { Jurnal } 3 \\
\text { (Weiner., } \\
\text { dkk) }\end{array}$ & $\begin{array}{l}\text { Enhancement dan } \\
\text { delineation tumor } \\
\text { tampak kurang jelas }\end{array}$ & $\begin{array}{l}\text { Enhancement dan } \\
\text { delineation tumor } \\
\text { tampak lebih baik }\end{array}$ \\
\hline
\end{tabular}

Dari tabel perbandingan peranan teknik split bolus antar literature didapatkan peranan teknik split bolus terhadap kualitas citra pada pemeriksaan MSCT leher menurut literatur, yaitu :

a. Pada pasien metastasis mampu mengurangi artefak yang disebabkan karena adanya media kontras berlebih pada BCV yang mengganggu gambaran kelenjar getah bening pada area cervicothoracic junction sehingga gambaran kelenjar getah bening tampak lebih jelas.

b. Pada pasien tumor dapat meningkatkan enhancement tumor dan memperjelas delineation tumor.

\section{Pembahasan}

1. Teknik Split-Bolus pada pemeriksaan MSCT Leher

Dari hasil analisis jurnal yang telah dilakukan, terdapat beberapa faktor yang perlu diperhatikan dari penggunaan teknik split-bolus pada pemeriksaan MSCT leher diantaranya media kontras yang digunakan (jenis, volume, dan konsentrasi media kontras) dan teknik injeksi media kontras (pembagian media kontras, penggunaan saline, flow rate, dan Scan delay time).

\section{a. Media kontras yang digunakan}

Saade dkk., (2016) menggunakan media kontras non ionik (Optiray $370 \mathrm{mg} / \mathrm{mL}$ ) dengan volume total media kontras yang digunakan $100 \mathrm{~mL}$. Lee dkk., (2012), menggunakan media kontras non ionik (Omnipaque, iohexol $300 \mathrm{mg} / \mathrm{mL}$ ) dengan volume total media kontras yang digunakan $80-100 \mathrm{~mL}$. Sedangkan Weiner $d k k$., (2010) menggunakan media kontras non ionik (Iopromide $300 \mathrm{mg} / \mathrm{L}$ ) dengan volume total media kontras yang digunakan $100 \mathrm{~mL}$.

Ketiga jurnal yang digunakan menggunakan media kontras iodine non ionik, media kontras jenis ini sering digunakan karena tingkat keamanannya yang cukup tinggi. Dalam sebuah studi retrospective (Katayama $d k k .$, 1990) yang melibatkan lebih dari 100.000 sample administrasi media kontras, ketika dikelompokkan berdasarkan usia dan penggunaan media kontras iodinasi nonionik, menunjukkan bahwa pasien yang berusia kurang dari 10 tahun dan orang tua memiliki tingkat reaksi merugikan yang terendah. Selain itu, pada penelitian tentang identifikasi risiko dan pencegahan terhadap Nefropati akibat kontras (Wijaya dan Atmadja, 2016) menyatakan bahwa efek samping dari media kontras iodine non ionik, termasuk CIN, jarang terjadi pada pasien dengan fungsi ginjal yang baik dan stabil.

Jurnal 1, 2, dan 3 menggunakan media kontras dengan volume total $80-100 \mathrm{~mL}$. Volume total media kontras yang digunakan tidak disesuaikan dengan indeks massa tubuh pasien tetapi sejalan dengan volume yang diberikan dalam literatur saat ini yaitu $100 \mathrm{~mL}$ dengan konsentrasi $300 \mathrm{mg} / \mathrm{mL}$ (Kyongtae T Bae, 2010; Weininger $d k k$., 2011; Saade $d k k$., 2016). Sedikit berbeda dengan yang lain, Saade $d k k$., (2016) menggunakan media kontras dengan konsentrasi 370 $\mathrm{mg} / \mathrm{mL}$. Namun penggunaan media kontras dengan konsentrasi $370 \mathrm{mg} / \mathrm{mL}$ masih masuk dalam rentang konsentrasi media kontras yang digunakan dalam pemeriksaan MSCT (Kyongtae T Bae, 2010) yakni 240-370 mg/mL. Pemilihan konsentrasi media kontras yang tepat tergantung pada beberapa faktor seperti ketersediaan media kontras, tujuan klinis, konfigurasi CT Scan, injektor, dan biaya.

Pada jurnal penelitian yang dilakukan oleh Lee dkk., (2012), Teknik split-bolus terbukti mampu mengurangi total volume media kontras yang digunakan pada pemeriksaan MSCT leher. Mereka membandingkan antara penggunaan volume media 
kontras $80 \mathrm{ml}$ dengan teknik split-bolus dibandingkan dengan $100 \mathrm{ml}$ media kontras tanpa teknik split-bolus dengan pengaturan flow rate dan scan delay time yang sama. Hasilnya nilai atenuasi vena lebih tinggi secara signifikan pada pemeriksaan MSCT leher dengan teknik split-bolus (209.0 \pm 34.1) dibandingkan pemeriksaan MSCT leher tanpa teknik split-bolus $(182.9 \pm 21.2)$. Nilai atenuasi arteri pemeriksaan MSCT leher tanpa teknik split-bolus dan teknik splitbolus masing-masing 177,0 \pm 19.8 dan $179.4 \pm 22.7$. Tidak ada perbedaan signifikan yang dicatat antara keduanya. Atenuasi kelenjar getah bening, kelenjar ludah, dan otot tidak menunjukkan perbedaan yang signifikan antara kedua teknik yang digunakan.

Dari pembahasan diatas, penulis sependapat bahwa pada pemeriksaan MSCT leher dengan teknik split-bolus menggunakan media kontras iodine non ionic dengan volume total media kontras $80-100 \mathrm{~mL}$ dan konsentrasi 300-370 mg/mL.

\section{b. Injeksi Media Kontras}

Split-bolus merupakan sebuah modifikasi dari pola injeksi media kontras dengan membagi media kontras menjadi 2 bolus. Pembagian media kontras dan flow rate yang digunakan berbeda pada setiap jurnalnya. Saade $d k k$., (2016) membagi media kontras dengan perbandingan $3: 2$ dari total volume untuk bolus 1 dan 2 dengan flow rate $2.5 \mathrm{~mL} / \mathrm{s}$ diikuti injeksi saline. Lee dkk., (2012) membagi media kontras masing-masing $1 / 2$ dari total volume untuk bolus 1 dan 2 dengan flow rate $2-3 \mathrm{~mL} / \mathrm{s}$ dengan delay interbolus yang berbeda. Sedangkan menurut Weiner $d k k$., (2010) pembagian media kontras dilakukan menggunakan perbandingan $3: 2$ dari total volume untuk bolus 1 dan 2 dengan flow rate $3 \mathrm{~mL} / \mathrm{s}$ dengan delay interbolus $60 \mathrm{~s}$.

Sebuah penelitian (Kim $d k k ., 2017)$ menyatakan pembagian media kontras pada teknik split-bolus dilakukan dengan injeksi $1 / 2$ dari total volume media kontras, diikuti oleh volume yang sama dari injeksi saline. Tiga puluh detik setelah dimulainya bolus pertama, bolus kedua disuntikkan dan diikuti injeksi saline. Scanning dilakukan 25 detik setelah dimulainya injeksi bolus kedua. Teknik ini menghasilkan penggabungan fase arteri akhir dan gambar fase vena portal tanpa menggunakan bolus tracking. Pendapat ini diperkuat oleh penelitian dari Thomas $d k k$., (2014) yang mengembangkan prinsip tersebut pada pemeriksaan CT Scan multiregion pediatrik dengan teknik split-bolus sehingga didapatkan saline dengan jumlah yang disesuaikan agar durasi injeksi menjadi 30 - 40 detik di bolus pertama dan bolus kedua dimulai 15-25 detik sebelum scanning.

Pada ketiga sumber utama yang digunakan penulis, semua pemeriksaan MSCT leher dengan teknik split-bolus menggunakan saline chaser. Penambahan saline dapat mengurangi jumlah volume media kontras yang dibutuhkan, tidak menghasilkan peningkatan vaskular yang lebih baik atau windows diagnostik yang lebih luas, tetapi dapat mengurangi artefak perivenous, dibandingkan dengan pemeriksaan yang hanya menggunakan bahan kontras saja. Saline mendorong ujung bolus kontras yang disuntikkan ke sirkulasi pusat, memungkinkan pemanfaatan media kontras yang lebih baik (You $d k k$., 2007; Eisenmenger dan Wiggins, 2015).

Flow rate yang digunakan mempengaruhi window time atenuasi pembuluh darah yang cukup. Untuk CT spiral kepala dan leher, yang menggunakan $100 \mathrm{~mL}$ media kontras intravena dengan konsentrasi $300 \mathrm{mg} / \mathrm{mL}$, laju injeksi optimal adalah $2 \mathrm{~mL} / \mathrm{s}$ (Groell dkk., 2001; Kyongtae T Bae, 2010). Berbeda dengan penelitian sebelumnya, penelitian yang dilakukan oleh Lee $d k k$., (2012) menunjukkan bahwa, dengan injeksi media kontras tanpa teknik split-bolus, atenuasi pembuluh darah dengan flow rate $2 \mathrm{~mL} / \mathrm{s}$ tidak berbeda secara signifikan dibandingkan dengan menggunakan flow rate $3 \mathrm{~mL} / \mathrm{s}$. Namun, dengan time delay yang sama, injeksi kontras split-bolus lebih efektif untuk peningkatan atenuasi pembuluh daripada modulasi flow rate.

Ketiga jurnal yang digunakan penulis menggunakan Fixed Scan delay time. Scan delay time yang digunakan pada jurnal 1, 2, dan 3 bebeda-beda, rentang waktu yang digunakan dari 70-120 detik, dihitung dari awal bolus pertama sampai awal scanning dengan delay interbolus berbeda-beda. Sedangkan menurut Bae (2010), untuk pemeriksaan MSCT leher rentang scan delay time yang digunakan dari 50 hingga 90 detik. Namun, penggunaan scan time delay yang lebih lama tidak menunjukan perbedaan yang signifikan, dibuktikan dengan hasil penelitian yang dilakukan oleh Lee $d k k$., (2012). Meskipun delay time teknik split bolus lebih lama (120 s), atenuasi arteri dan vena tidak berbeda secara signifikan dari dua injeksi tanpa teknik split bolus. Atenuasi arteri setelah injeksi dengan teknik split bolus secara signifikan lebih tinggi daripada setelah injeksi tanpa teknik split bolus. Atenuasi vena setelah injeksi dengan teknik split bolus secara signifikan lebih tinggi daripada setelah injeksi tanpa teknik split bolus. Atenuasi kelenjar getah bening, kelenjar ludah, dan otot tidak menunjukkan perbedaan yang signifikan antar protokol.

Berdasarkan literature tersebut, penulis sependapat bahwa pembagian media kontras pada bolus pertama dan kedua dapat dilakukan dengan perbandingan 3 : 2 maupun 1 : 1 diikuti dengan injeksi saline. Flow rate yang digunakan antara 2-3 $\mathrm{mL} / \mathrm{s}$ dengan fixed scan time delay antara 70-120 detik. 


\section{Peranan teknik Split-Bolus terhadap kualitas citra} yang dihasilkan pada pemeriksaan MSCT Leher

Hasil penelitian yang dilakukan oleh (Saade $d k k$., 2016) menunjukan bahwa dengan menggunakan teknik split-bolus (empat fase) dapat meningkatkan enhancement arteri dan mengurangi enhancement vena sehingga enhancement vaskuler (vena dan arteri) lebih homogen, mengurangi artefak opasifikasi arteri dan vena pada cervicothoracic junction. Enhancement vaskuler yang homogen memperjelas delineation antara pembuluh darah dan kelenjar getah bening. Teknik split-bolus menunjukkan peningkatan signifikan $(\mathrm{P}<.0001)$ dalam AVCR di berbagai area anatomi. Rata-rata CNR untuk teknik split-bolus secara signifikan lebih tinggi daripada tanpa teknik split-bolus pada semua level anatomi, (teknik split-bolus, 34,4 HU +/- 9.0; tanpa teknik split-bolus, 14.5 HU +/- 14.0; P < .0313). Selain itu penggunaan teknik split-bolus mampu mengurangi artefak yang disebabkan karena adanya media kontras berlebih pada BCV yang mengganggu gambaran kelenjar getah bening pada area cervicothoracic junction.

Berdasarkan hasil penelitian yang dilakukan oleh Weiner dkk., (2010), teknik split-bolus menghasilkan densitas rata-rata yang lebih tinggi secara signifikan pada tumor $(118 \pm 30 \mathrm{HU})$ dibandingkan tanpa teknik splitbolus $(82 \pm 17 \mathrm{HU}, \mathrm{p}<0,001)$. Perbedaan dalam densitas rata-rata di kelenjar submandibular $(98 \pm 35 \mathrm{HU}$ vs $79 \pm$ $20 \mathrm{HU})$ dan otot sternocleidomastoid $(69 \pm 8 \mathrm{HU}$ vs $64 \pm$ $7 \mathrm{HU}$ ) tidak mencapai signifikansi (masing-masing $\mathrm{p}=$ $0,1$ dan 0,08$)$. Pada arteri karotis $(311 \pm 65 \mathrm{HU}$ vs $203 \pm$ $46 \mathrm{HU})$ dan vena jugularis $(267 \pm 87 \mathrm{HU}$ vs $199 \pm 40$ HU) menunjukkan peningkatan yang secara signifikan lebih tinggi pada kelompok split-bolus, masing-masing $\mathrm{p}$ $<0,001$ dan $\mathrm{p}<0,01$. Teknik bifasik (split-bolus) mampu menampilkan enhancement tumor dan pembuluh darah lebih baik dari pada teknik monofasik (tanpa split-bolus). Enhancement jaringan lunak (kelenjar submandibular dan otot sternokleidomastoid) tidak menunjukkan perbedaan yang signifikan antara kedua teknik.

Penelitian yang dilakukan oleh Lee $d k k$., (2012) menyatakan bahwa atenuasi arteri dan vena setelah injeksi dengan teknik split-bolus secara signifikan lebih tinggi daripada setelah injeksi tanpa teknik split-bolus. Atenuasi kelenjar getah bening, kelenjar ludah, serta otot tidak menunjukkan perbedaan yang signifikan antara kedua teknik. Teknik split-bolus mampu meningkatkan enhancement vaskuler tanpa mengurangi enhancement parenkim maupun lesi.

Kualitas citra yang dihasilkan pada pemeriksaan dengan menggunakan teknik split-bolus terbukti lebih baik dilihat dari hasil diagnosis akhir yang dibuktikan dengan pembedahan pada penelitian yang dilakukan oleh Saade $d k k$., (2016). Pada pemeriksaan tanpa teknik splitbolus diagnosis radiologis akhir yang termasuk limfadenopati pada 15 dari 50 pasien, dengan empat simpul nekrotik, termasuk satu simpul lebih kecil dari 10 $\mathrm{mm}$ dan tiga simpul lebih besar dari $10 \mathrm{~mm}$, dengan simpul yang tersisa memiliki tampilan normal. Secara bedah, semuanya dikonfirmasi dengan perbedaan enam kelenjar getah bening metastasis (dua node $<10 \mathrm{~mm}$ dan empat node $10 \mathrm{~mm}$ ) yang tidak divisualisasikan selama pemeriksaan MSCT. Pada pemeriksaan dengan teknik split-bolus, limfadenopati ganas ditemukan pada 12 dari 50 pasien; dengan kelenjar getah bening nekrotik lebih kecil dari $10 \mathrm{~mm}$ pada empat dari 50 dan lebih besar dari $10 \mathrm{~mm}$ pada delapan dari 50; node yang tersisa memiliki tampilan normal. Tidak ada perbedaan antara hasil pembedah dengan laporan radiologi.

Data dari 3 sumber utama tersebut sesuai dengan practice parameter untuk pemeriksaan CT exstracranial kepala dan leher menurut ACR., ( 2015), Eisenmenger dan Wiggins (2015) yang menyatakan bahwa teknik splitbolus pada pemeriksaan MSCT leher mampu meningkatkan enhancement lesi dan vaskuler. Hal ini membuktikan bahwa teknik split-bolus berperan terhadap kualitas citra yakni kontras resolusi dan penggunaan teknik split-bolus lebih baik dibandingkan dengan teknik monofasik dilihat dari citra yang dihasilkan pada pemeriksaan.

Berdasarkan literature tersebut penulis sependapat bahwa kualitas citra yang dihasilkan pada pemeriksaan MSCT leher dengan menggunakan teknik split-bolus lebih baik dibandingkan dengan pemeriksaan MSCT leher tanpa menggunakan teknik split-bolus. Teknik split-bolus mampu meningkatkan enhancement vaskuler tanpa mengurangi enhancement parenkim dan lesi. Pada pasien dengan klinis metastasis penggunaan teknik split-bolus mampu mengurangi artefak pada arteri dan vena karena media kontras yang berlebih sehingga enhancement kelenjar getah bening lebih baik. Sedangkan pada pasien tumor, penggunaan teknik split-bolus mampu meningkatkan enhancement tumor dan memperjelas batas tumor. Hal ini menunjukan bahwa teknik split-bolus berperan terhadap kontras resolusi pada citra yang dihasilkan yakni dapat menampilkan enhancement lesi dan vaskuler yang lebih baik.

\section{Kesimpulan}

1. Teknik split-bolus pada pemeriksaan MSCT leher menurut data literature dilakukan menggunakan media kontras iodine non ionic dengan volume $80-100 \mathrm{~mL}$ dan konsentrasi $300-370 \mathrm{mg} / \mathrm{mL}$. Media kontras iodine non ionic digunakan karena memiliki tingkat keamanan tinggi, volume total dan konsentrasi media kontras yang digunakan didasarkan pada literature yang ada saat ini. Pembagian bolus pertama dan kedua menggunakan perbandingan $3: 2$ atau $1: 1$ dari total volume kontras diikuti dengan injeksi saline. Media kontras diinjeksikan dengan flow rate $2-3 \mathrm{~mL} / \mathrm{s}$ menggunakan fixed scan delay time dari 70 - 120 detik.

2. Teknik split-bolus pada pemeriksaan MSCT leher berperan terhadap kualitas citra yang dihasilkan, yakni pada kontras resolusi. Teknik split-bolus mampu meningkatkan enhancement vaskuler tanpa mengurangi enhancement 
parenkim dan lesi. Selain itu, pada pasien dengan klinis metastasis penggunaan teknik split-bolus mampu meningkatkan enhancement arteri dan mengurangi enhancement vena sehingga enhancement vaskuler lebih homogen serta mampu mengurangi artefak pada arteri dan vena karena media kontras yang berlebih sehingga enhancement kelenjar getah bening lebih baik. Sedangkan pada pasien tumor, penggunaan teknik split-bolus mampu meningkatkan enhancement tumor dan memperjelas batas tumor.

\section{Saran}

1. Perlu dilakukan penelitian mendalam mengenai pembagian volume media kontras pada bolus pertama dan kedua yang digunakan pada pemeriksaan MSCT leher dengan teknik split-bolus perlu dilakukan karena literature yang ada saat ini menggunakan pembagian volume media kontras yang berbeda-beda.

2. Penggunaan teknik split bolus pada pemeriksaan MSCT leher dapat digunakan pada pasien dengan klinis tumor dan metastasis karena mampu meningkatkan enhancement tumor, memperjelas batas tumor, dan mampu memperlihatkan kelenjar getah bening dengan lebih jelas.

\section{Daftar Pustaka}

ACR (2015) "ACR - ASER - SPR Practice Parameter for the Performance of CT head/neck," 1076(Revised 2008), hal. 1-18.

ACR Manual on Contrast Media Version 10.3 (2018) Media. ACR Committee on Contrast Media and Drugs.

Applegate, E. J. (2010) "Anatomical Review of the Neck," in The Sectional Anatomy Learning System. 3 ed. U.S: Elsevier Inc., hal. 195.

Bae, Kyongtae T. (2010) "Intravenous contrast medium administration and scan timing at CT: Considerations and approaches," Radiology, 256(1), hal. 32-61. doi: 10.1148/radiol.10090908.

Boos, J. $d k k$. (2017) "Split-bolus injection producing simultaneous late arterial and portal venous phases in CT enterography: Preliminary results," American Journal of Roentgenology. doi: 10.2214/AJR.17.18034

Docherty, N. (2012) "Netter's head and neck anatomy for dentistry, 2nd edition," British Dental Journal. doi: 10.1038/sj.bdj.2012.517.

Drake, R. L., Vogl, A. W. dan Mitchell, A. W. . (2015) "Gray's Anatomy for Students, Third Edition," Gray's Anatomy for Students. doi: 10.1017/CBO9781107415324.004.

Eisenmenger, L. B. dan Wiggins, R. H. (2015) "Imaging of Head and Neck Lymph Nodes," Radiologic Clinics of North America. Elsevier Inc, 53(1), hal. 115-132. doi: 10.1016/j.rcl.2014.09.011.

Groell, R. $d k k$. (2001) "Contrast-enhanced helical CT of the head and neck: Improved conspicuity of squamous cell carcinoma on delayed scans," American Journal of Roentgenology. doi: 10.2214/ajr.176.6.1761571.

Hiatt, J. L. dan Gartner, L. P. (2010) Textbook of Head and Neck Anatomy. 4 ed. Philadelphia: Lippincott Williams \& Wilkins.

Jeavons, C. $d k k$. (2018) "A review of split-bolus single-pass CT in the assessment of trauma patients," Emergency Radiology. doi: 10.1007/s10140-018-1591-1.

Katayama, H. dkk. (1990) "Adverse reactions to ionic and nonionic contrast media. A report from the Japanese Committee on the Safety of Contrast Media," Radiology. doi: 10.1148/radiology.175.3.2343107.

Kim, Y. H. $d k k$. (2017) "Simplified split-bolus intravenous contrast injection technique for pediatric abdominal CT," Clinical Imaging. Elsevier Inc., 46(March 2014), hal. 28-32. doi 10.1016/j.clinimag.2017.06.002.

Laghi, A. (2012) MDCT Protocols. Verlag: Springer International Publishing.
Lee, J. H. dkk. (2012) "Usefulness of Biphasic Contrast Injection in Multidetector CT of the Head and Neck: A Comparison with Monophasic Contrast Injection," Journal of the Korean Society of Radiology. doi: 10.3348/jksr.2012.67.2.85.

Mahesh, M. (2013) "The Essential Physics of Medical Imaging, Third Edition." Medical Physics. doi: 10.1118/1.4811156.

Mittal, D. dan Dhawan, S. (2019) "Role Of Contrast Enhanced Computed Tomography In Cervical Lymphadenopathy In Head and Neck Malignancy," 18(6), hal. 23-30. doi: 10.9790/0853-1806072330.

National Cancer Institute (2019) Definition of soft tissue - NCI Dictionary of Cancer Terms - National Cancer Institute, National Cancer Institute. Tersedia pada: https://www.cancer.gov/publications/dictionaries/cancerterms/def/soft-tissue?redirect=true (Diakses: 31 Januari 2020).

Romans, L. E. (2011) Computed Tomography for Technologist: A Comprehensive Text. Philadelphia: Wolters Kluwer Health|Lippincott Williams \& Wilkins.

Saade, C. dkk. (2016) "Comparison of Standard and Quadruple-Phase Contrast Material Injection for Artifacts , Image Quality , and Radiation Dose in the Evaluation of Head," RSNA, 279(2), hal 571-577. doi: 10.1148/radiol.2015150511.

Scialpi, M. $d k k$. (2014) "Split-bolus versus triphasic multidetector-row computed tomography technique in the diagnosis of hepatic focal nodular hyperplasia: A case report," Journal of Medical Case Reports, 8(1), hal. 4-9. doi: 10.1186/1752-1947-8-425.

Scialpi, M. $d k k$. (2015) "Single-phase whole-body 64-MDCT split-bolus protocol for pediatric oncology: Diagnostic efficacy and dose radiation," Anticancer Research, 35(5), hal. 3041-3048.

Scialpi, M. dan Schiavone, R. (2019) "Diagnostic efficacy of single-pass split-bolus multidetector computed tomography in pediatric oncology: a valid alternative to a standard monophasic protocol," Pediatric Radiology. Pediatric Radiology, 49(1), hal. 151-152. doi: 10.1007/s00247-018-4234-5.

Seeram, E. (2016) Computed Tomography: Physical Principles, Clinical Applications, and Quality Control. 4 ed. Missouri: Elsevier Inc.

Weiner, G. M. $d k k$. (2010) "Monophasic versus biphasic contrast application in CT of patients with head and neck tumour," EPOS ESR Scintific Exhibit, C-3331 ECR, hal. 1-8. doi: 10.1594/ecr2010/C-3331.

Weininger, M. $d k k$. (2011) "Cardiothoracic CT angiography: Current contrast medium delivery strategies," American Journal of Roentgenology. doi: 10.2214/AJR.10.5814.

Wijaya, A. T. dan Atmadja, B. (2016) "NEFROPATI AKIBAT KONTRAS Risk Identification and Prevention of Contrast-Induced Nephropathy," 2(September 2016), hal. 52-58.

Wijokongko, S. dkk. (2016) Protokol Radiologi CT-Scan dan MRI. Magelang: Inti Medika Pustaka.

You, S. Y. $d k k$. (2007) "Effects of right- versus left-arm injections of contrast material on computed tomography of the head and neck," Journal of Computer Assisted Tomography. doi: 10.1097/RCT.0b013e318038d8fb. 